\title{
The Teacher as an Agent of Meaningful Educational Change
}

\author{
Saloshna Vandeyar ${ }^{1}$ \\ University of Pretoria
}

\begin{abstract}
This paper peers through the window to look at how a teacher brings about meaningful educational change in a diverse classroom. Utilizing three sets of arguments from the field of educational change, I traced educational change within a teacher during the course of an academic year. Data capture comprised a mix of semi-structured interviews and observations. Findings were multi-fold: First, the teacher's professed beliefs cohered well with her practices and played a significant role in how she responded to diversity in the classroom. Second, if change attempts are to be successful, individuals must find meaning concerning what should change as well as how to go about it. In the South African context there is much literature on what should change, but there is very little on what strategies and programmes can be implemented to effect change in teachers' beliefs about diversity. The educational literature underscores the centrality of the personal domain of the teacher in sustaining educational change. This paper illustrates that the concept of identity is a social, historical, and generational construct that is fluid and susceptible to change. It shows how change can be sustained in the personal domain of the teacher and illustrates that teaching is ultimately a class act of human compassion.
\end{abstract}

Keywords

Diversity $\bullet$ Educational change $\bullet$ Teacher beliefs $\bullet$ Teacher practice $\bullet$ Sociocultural responsive education $\bullet$ Human compassion

1 Correspondence to: Saloshna Vandeyar (PhD), Department of Humanities Education, University of Pretoria, Pretoria 0001 South Africa. Email: Saloshna.Vandeyar@up.ac.za

Citation: Vandeyar, S. (2017). The teacher as an agent of meaningful educational change. Educational Sciences: Theory \& Practice, 17, 373-393. http://dx.doi.org/10.12738/estp.2017.2.0314 
They fill me with a most beautiful variety of multicultural love, humor, religions and they make me the richest person in the world!

Over the past two decades the South African education system has been subjected to a barrage of education reform efforts. The advent of democracy witnessed a change in the educational paradigm from Christian National Education (CNE) to Outcomesbased education (OBE), which brought about a radical change in the School Curriculum. Curriculum 2005 was introduced in 1996, followed by the Revised National Curriculum Statement (RNCS) in 2002, the Curriculum Assessment Policy Statement (CAPS) in 2012 and the recently introduced Schooling 2025 in 2014.

Synchronized with these curricular reform initiatives were professional development programmes, the aim of which was to help teachers understand the new curriculum reforms, and changes in the teacher appraisal system. Teacher development programmes were large scale efforts that took the form of the cascade model and were found to be far from adequate (Jansen \& Christie, 1999; Jansen \& Taylor, 2003; Taylor \& Vinjevold, 1999). The result was the "watering down and/or misinterpretation of crucial information" (Fiske \& Ladd, 2004, p. 162). In 2003 the Department of Education integrated the existing quality management programmes (Developmental Appraisal System [DAS], 1998; Performance Measurement System [PM], 2003; Whole School Evaluation [WSE], 2005) into one and introduced the Integrated Quality Management System (IQMS) as an instrument used to assess the performance of teachers. The abovementioned initiatives were all geared towards bringing about meaningful educational change. However, little if any attention was given to the teacher as an agent of educational change and the role of teacher beliefs in effecting educational change. Accordingly, this study asks how does a teacher bring about meaningful educational change in a diverse classroom. What are teachers' beliefs about diversity? Can teachers change their ingrained beliefs about diversity? How does educational change manifest in such a context?

The argument is presented as follows. I briefly sketch the background context to situate the identified intellectual puzzle. I then present a review of the literature on educational change and teacher beliefs. Thereafter a brief exposition of the theoretical framework that is utilized in this study is presented. The paper concludes with a critical engagement between findings of this study and the literature on educational change to unpack how a teacher can bring about meaningful educational change in a diverse classroom.

\section{Background Context ${ }^{2}$}

Educational reforms in South Africa have been framed by legislative policies that promote democracy and human rights. The South African Schools Act (Act no. 37 of

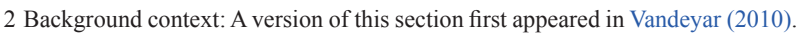


1997) catalyzed by the Bill of Rights and the South African Constitution formalized the process of desegregation of schools in South Africa. As a result of these Constitutional measures, the public schooling system in South Africa has undergone radical changes. These Constitutional measures created the opportunity for students from diverse cultural backgrounds to attend public schools of their choice.

The movement of students into "schools of their choice" naturally had a profound impact on schools and elicited a series of reactions from various stakeholders within the schooling system. Various dynamics were at play at the macro (national education) and meso (school governing bodies) levels of the education system, in an attempt to relieve the tension created by recent educational reforms and to address the issue of power. Of crucial importance however, are the dynamics at the micro-level (classroom) -the process of policy appropriation or misappropriation by teachers mediating between policy and its actual practice on the classroom floor.

One of the assumptions underlying this nationally directed educational reform process is that teachers will be both willing and able to adapt their teaching practices accordingly. Yet, there is considerable evidence to suggest that this is not so (Harley \& Wedekind, 2004; Jansen, 2001; Jita, 2002; Sieborger \& Nakabugo, 2001; Vandeyar, 2006; Vandeyar \& Jansen, 2008; Vandeyar \& Killen, 2003). These educational reforms set new and more challenging demands on teachers, which were often in conflict with their beliefs and value systems. Many teachers were trained in the previously segregated education system, with the understanding that they would only be teaching students from a particular race group. Some teachers now had to come to terms with teaching through the medium of their second language and to students who were incompetent in the language of instruction. These demands have placed tremendous stress on teachers and have influenced their identities, beliefs and value systems. The majority of Black students are fluent in their mother tongue, which is one or more of the indigenous languages of South Africa. However, many of these students, because of existing educational infrastructures and trends of globalization, are now striving to obtain an education through the medium of English, which for some is a third or even a fourth language. These students view English as an avenue to upward mobility, hence their choice is based on this criteria.

Although the abovementioned constitutional measures set the stage for desegregation to unfold at schools by establishing the physical proximity of members of different groups in the same school, it did not go further to interrogate the quality of contact; not only in the personal attitudes of students and teachers but also in the institutional arrangements, policies and ethos of the school (Sayed, 2001, p. 254). 


\section{Understanding Educational Change}

A review of the voluminous literature reveals some distinctive characteristics of the concept of educational change. Change is a complex process that happens within an organizational ecology (Hargreaves, 2000; Hopkins, 2000) is difficult to achieve (Fullan, 2000; Sarason, 1996) operates on three levels namely, symbolic, linear, and appropriation (Fullan, 1991, 2003) and is often an expression of political symbolism (Goodson, 2001). Changing the ways in which teachers teach or students learn and changing the curriculum without also changing the teachers, the classroom, the school, and the community, might not achieve the desired outcomes. Change is linear, in that it occurs down an authoritative succession of participants. Change in itself whether top-down or bottom-up does not guarantee meaningful change. Change appropriation refers to the change in meaning of one's experience. Teachers often believe that they have changed in response to a particular reform when in fact they might only have changed superficially, or not at all.

Educational change also moves through distinctive stages of initiation, implementation, and institutionalization. People who encounter changes go through successive "stages of concern" and respond very differently to educational change initiatives, depending on what point they have reached in their own lives and careers. Fullan (2000, p. 224) identified two dimensions of capacity for change. One of which is what individuals can do to develop their effectiveness as change agents, despite the system, and the other is how systems need to be transformed. He argues that teachers cannot depend on or wait for the system to change. This is all the more convincing when we realize that according to chaos theory, change is non-linear and that systems are not entirely coherent. If more individuals act as learners, connect with kindred spirits, speak out and work with those who have different views, then it is likely that systems will learn to change.

Educational change mandates what changes to implement and how to implement them. These aspects interact and shape each other (Fullan, 2001). Given the plethora of meanings and characteristics of the concept of educational change, how then does one go about implementing educational change? Fullan (1998) argues that understanding a problem and identifying the changes needed to correct them are entirely separate steps from knowing how to bring these changes about. Fullan (2001, p. 38) claims that the implementation of educational change involves "change in practice" along three dimensions for it to have a chance of affecting an outcome: (1) the possible use of new or revised material, including instructional resources such as curriculum materials or technologies; (2) the possible use of new teaching approaches; and (3) the possible alteration of beliefs such as the pedagogical assumptions and theories underlying new policies or programmes. Several authors (Ball \& Cohen, 1999; National Research Council, 1999; McLaughlin \& Mitra, 2000; Sheehy, 1981; Stigler 
$\&$ Hiebert, 1999) support Fullan's claim about the alteration of beliefs and argue that changes in belief and understanding are the foundation of achieving lasting reform because they are based on fundamental changes in conception, which, in turn, relate to skills and materials. The challenge that arises is in how teachers negotiate the relationship between new reform efforts and the subjective realities embedded in their individual and organizational contexts and their personal histories. How these subjective realities are addressed is crucial for whether potential changes become meaningful at the level of individual use and effectiveness (Fullan, 2001).

\section{Teacher Beliefs in the Diverse Classroom}

Teacher beliefs play a pivotal role in the diverse classroom. Beliefs may influence how teachers teach (Kagan, 1992; Kauchak \& Burbank, 2003; Nespor, 1987; Wilson $\&$ Cooney, 2003) and understand diversity (Reinke \& Moseley, 2002; Sleeter 1992). Not only are teachers' beliefs context-specific (Ambrose, Clement, Phillip, \& Chavot, 2004) but they also influence the implementation of multicultural education (Goodwin 1997; Ladson-Billings, 1995; Pohan, 1996). Teachers' beliefs have an influence on their perceptions and ultimately, their behavior (Corbett \& Wilson, 2002). Thompson's (1992) review of the literature points to the fact that sometimes teachers' professed beliefs cohered well with their practices (Mitchell \& Koedinger, 2000). Thus having an understanding of teacher belief structures is important to the improvement of teaching practices (Goodman, 1988). Bandura (1986) and Dewey (1933) asserted that beliefs were the most significant predictors of the decisions that individuals make throughout their lives. Consequently, teacher beliefs are a significant factor in how they respond to diversity in the classroom (Reinke \& Moseley, 2002).

Learning to teach diverse students requires that teachers examine their beliefs about teaching and explore the effectiveness of their practices in accommodating the various cultures, lifestyles, and learning styles of their students (Cabello \& Burstein, 1995, p. 285).

The socialization process of teachers through means such as their own schooling experiences, observed classroom practices, family and community responses to diversity, results in the development of individual belief systems. These belief structures help to organize and accept or reject new incoming information (Walsh \& Charalambides, 1990). As a result, teaching practices are overwhelmingly based on the teacher's background and experiences (Baca \& Cervantes, 1989). Spradley and McCurdy (1987, pp. 2-3) further explain the role of beliefs regarding diversity.

We tend to think that the norms we follow represent the 'natural' way human beings do things. Those who behave otherwise are judged morally wrong. This viewpoint is ethnocentric, which means that people think their own culture represents the best, or at least the most appropriate way for human beings to live. 
Beliefs are developed during the early stages of life and determine our ideas about the world. According to Ross (1994), beliefs are inferences that are derived from past experiences and unconscious associations. Beliefs involve moods, feelings, emotions, and subjective evaluations that are stored in one's long-term memory, and contribute to the power of one's associations (Leder, Pehkonen, \& Törner, 2002; Nespor, 1987). According to Mueller (1986) and Lloyd (2003) beliefs are representations of the information a person has about an object, person, group of people, and so forth, which may be based on fact or on one's opinion, of which stereotypes are a good example. Beliefs unlike knowledge tend to be resistant to change (Schraw \& Olafson, 2002). Knowledge may vary according to additional information and diverse expectations. Beliefs, on the other hand, tend to maintain their suppositions unless there is a "conversion" or "gestalt shift" (Nespor, 1987). Garibaldi (1992) suggests that, in contemporary society, teachers' beliefs about diversity have been influenced by information, which reinforces stereotypes rather than disarms them.

With the increasing number of students from diverse cultures entering schools, the demands for a community of teachers who can communicate with children from different cultural backgrounds has increased (Banks \& Banks, 2001). These cultural backgrounds provide a frame of reference that defines one's heritage, values and social traditions. Aikenhead (1996) argues that teachers may assume the culture and values of familiar subcultures in which they grow up, but they must often cross cultural borders into new subcultures to be successful participants in different environments. Crossing cultural borders requires renegotiations of beliefs and ideas as teachers understand and assimilate the values and beliefs within different subcultures (Aikenhead, 1996). The ability of teachers to understand their own belief systems as well as the value systems of their learners may affect how successful they are in responding to diversity in the classroom.

\section{Theoretical Moorings: Subjective Realities of Educational Change}

The theoretical framework for the study includes two constructs, namely, the personal domain of educational change and identity. Goodson's (2001) theory emphasizes the centrality of the personal domain of the teacher in sustaining educational change. He examines the segments in the educational change process and argues that in addition to internal and external segments, increasing attention needs to be paid to the personal missions and purposes that underpin teachers' commitment to change processes. He proposes that new models of educational change need to reinstate the balance between the internal, the external, and the personal perspectives on change. Models of change need to "acknowledge the force of personal identity projects under post-modernity which seeks new integration with internal missions" (Goodson, 2001, p. 59). If this new balance is not achieved, change forces will be neither humanized nor mobilized. 
Change will unfold as political symbolism, lacking personal or internal commitment or ownership. Several other authors agree with this statement and hence make the claim that educational change is most successful when conducted by teachers as part of their personal and professional projects and where teachers take ownership of the reform (Goodson \& Hargreaves, 1996; McClaughlin \& Yee, 1988; Sheehy, 1981). Sheehy (1981) argues that embracing change resonates with an inner change in people's beliefs. Change begins with a transformation of people's perceptions and projects outwards into the social and institutional domain. Personal change, which refers to the personal beliefs and missions that individuals bring to the change process, is given importance and thus the lens shifts to focus on how people change internally and personal change then influences institutional change.

Subjective realities are a product of one's identity. Roediger (2003) asserts that any study seeking to insert identity as an analytic category in the social process needs to problematize identity as socially, historically, and ideologically constructed, rather than accepting it as a biological or physical fact. As Roediger writes, identity is constructed differently across time by people of the same social class, and differently at the same time by people whose class positions differ. Hall (1996a; 1996b) argues that identity should be seen as something that is produced. Identity is created from the ingredients of a personal past but is always in a process of transformation. It focuses on becoming rather than on being and is formed in accordance with how one is positioned by and positions oneself in respect to the past. Identity is always influenced by culture, history, and power, which is combined in the concept of hybridity to enable us to understand the present circumstances of people. Gilroy (2004) proposes the idea of conviviality that refers to the process of cohabitation and interaction that have made multiculturalism an ordinary feature of social life. Conviviality makes nonsense of closed, fixed, and reified identity and turns attention toward the always unpredictable mechanisms of identification. The concept of identity, as opposed to being something that is stable and fixed, can thus be seen as a social, historical, and generational construct that is susceptible to change. The defining characteristics of hybridity, fluidity, and multiplicity compose the terrain of identity. Therefore, it becomes imperative that in continually re-defining identity, we build upon, negotiate, and mediate an existing identity in any given social context, thereby, affirming rather than negating or denying our identity.

\section{Research Strategy}

The meta-theoretical paradigm utilized in this study was that of social constructivism. The methodological paradigm employed a qualitative case study approach (Silverman, 2006). The aim of this study was to gain in-depth 'thick' descriptions and understandings of a specific social context or phenomenon. This paper re-examined data from the 
broader study that explored "best practice" in desegregated South African classrooms (Nkomo \& Vandeyar, 2008). I began with a broad canvas, traveling to schools across South Africa in an attempt to search for reputational samples not only of racial desegregation but also of social integration and to identify teachers that were bringing about change in their practice. Snowball sampling (Baltar \& Brunet, 2012; Rubin \& Babbie, 1993) fulfilled this requirement as principals' were requested to recommend teachers that were bringing about change in their schools.

While capturing data for the broader study, I came across Mrs Coetzee, an exceptional teacher using an "epistemology of compassion" (Vandeyar, 2010, 2013). Classroom observations of this teacher established some criteria that made her exceptional. She seemed to have extensive knowledge about each of her learners; she knew and understood each of their lives; she incorporated their life-worlds in her teaching and enabled learners to attach meaning to real life experiences. I acknowledge that in my role as a reactive observer I was part of the social setting under study. Reactive observations are contexts in which participants are mindful of being observed and are "amenable to interacting with the researcher" (Angrosino, 2005 , p. 732). I purposefully chose this role as a researcher because of the useful source of data that this approach could yield during observations.

Semi- structured interviews with Mrs Coetzee to determine her perspectives about the way in which the process of desegregation was unfolding in her classroom triangulated criteria used in observations. These interviews coincided with the threeweek period of observations. Field notes were taken, based on informal classroom observations. Attention was also given to the physical atmosphere of the classroom, which included observations of artifacts such as paintings, décor, photographs, portraits and school magazines. As in the broader study, observation was the main data gathering technique used in this study. Observed lessons were videotaped and interviews were audio recorded and transcribed.

Data garnered from the broader study was ripe for sub-analysis that focused on how a teacher brought about meaningful change in her classroom. Using content analysis methods (Mayring, 2000; Sandelowski, 2000), data was a priori re-coded (Charmaz, 2005) to accommodate "new insights" (Sandelowski, 2000, p. 338). The data was coded to make sense of emergent categories that expressed the experiential knowledge of the participant, and presented as rich and thick analysis.

To ensure research rigor the following quality criteria were considered namely, transferability, credibility, dependability, confirmability and authenticity. Transferability refers to the scope and the restrictions to which findings of this research can be applied. Credibility of the research findings included the purposeful sampling of the research participant, the sampling of the research site and the application 
of appropriate data gathering strategies (Butler-Kisber, 2010). Dependability was achieved by a process known as auditing. The audit trail procedure can also be valuable when verifying confirmability (Seale, 2002). The authenticity of this study rests in the "faithful reconstruction of the participant's multiple perceptions" (McMillan \& Schumacher, 2001, p. 415).

Ethical approval to conduct this study was received from the Ethics Committee at the Faculty of Education. The ethics application went through a rigorous blind peer review process. Pseudonyms were given to the research site and the participant to ensure anonymity and confidentiality.

\section{Findings: Portrait of an Exceptional Teacher in a Diverse Classroom ${ }^{3}$}

Mrs Coetzee, the Grade 5 teacher at Equity Primary, was white and in her late thirties. She completed her schooling and training as a teacher at Afrikaans-medium educational institutions. She has been teaching at Equity Primary school, a former Afrikaans-medium school situated in a former low-middle class white suburb, for the past 18 years. She says she "thought of primary school teaching, because I [she] wanted to make more of a difference." Her initial years of teaching occurred in the previous educational dispensation and she thus taught exclusively to white Afrikaans-speaking students. With the advent of democracy the student demography radically changed at the school. Her classroom comprised of forty learners. These learners were diverse in terms of race, gender, culture, ethnic groupings, language and socio-economic status.

I have more than eleven cultural groups in my class; more than eight religious groups and of course, two genders. My children also vary in social economic status. They fill me with a most beautiful variety of multicultural love, humor, religions and they make me the richest person in the world.

Mrs Coetzee took much pride in the appearance of her classroom. The climate of the classroom was inviting, welcoming and stimulating. Every available space in the classroom was filled with diverse cultural posters, pictures, artefacts, fabrics and sculptures that proudly boasted the "rainbow nation" of South Africa. The walls of the classroom were bright green in color and were adorned with learners' projects, posters and cultural artefacts that were representative of the class of diverse learners. Artistic drawings of learners, depicting the variety of cultural backgrounds, were draped above and across the classroom. Books were neatly stacked on three racks that projected from the wall on the front left-hand corner of the classroom. Plants and teddy bears that hugged each other were strategically perched on the book racks and windowsills around the classrooms. Proudly displayed on the top of the steel cabinet at the front right side of the classroom was the assagai (spear) and shield

3 This section of the data appeared in Vandeyar (2013). Copyright Permission has been granted by the journal to reproduce this article either in its entirety or parts of it. 
of Zulu origin. Juxtaposed against this was a miniature model of the ox-wagon of Afrikaner origin. Class rules were pinned up on the cupboard. It would seem that in terms of first order changes, Mrs Coetzee went to great lengths to create a culture of inclusivity and a sense of belonging for all her learners. Instead of just replacing one culture with another or retaining the hegemonic culture (Afrikaans) of the school, she chose to affirm all cultures and in so doing embraced the "rainbow nation."

I present the findings in the form of two classroom vignettes:

\section{Vignette 1}

This was an Arts and Culture lesson in a Grade 5 class. Mrs Coetzee was teaching the concept of racism. She had asked each learner to bring one fruit to class. The class comprised of forty learners. The class was divided into eight groups, each group comprised of five learners. Learners were seated in multicultural groups. Noise centred around activity and group work. Utensils were provided for each group to begin making a fruit salad.

Mrs Coetzee taught the concept of racism in a real-life and fun way. The lesson commenced with the sequencing of events that related to the life-world of her learners. When you wake up in the morning you bath, dress, make up your bed, eat breakfast and then come to school. Mrs Coetzee illustrated sequence and then brought in the idea that each person's sequence will be different. Subsequently she introduced the concept of sameness by emphasizing that if you do the same things every day it will become very boring, similarly if you eat only one type of fruit every day and no other fruit, "Will the banana get boring? Will the apple get boring?" Will the pears get boring?" Will the watermelon get boring? She then emphasized that we need variety and difference in our lives and introduced the concept of the fruit salad as a metaphor to teach the concept of racism. She taught the complex and dynamic concept of racism to Grade five learners by utilizing the simple method of making a fruit salad. She not only acknowledged differences but more importantly utilized it as an asset.

She was fully aware and constantly alert to the dynamics at play in diverse contexts. A boy in one of the groups gave a banana to one of the girls in his group and told her to peel it. Mrs Coetzee immediately picked up on gender bias and reacted in the following way: "Typical man, gives the banana to the woman to peel." "Doesn't your father's help in the kitchen? Please take that banana back and make sure you peel it."

She was also acutely aware of differences in the socio-economic status of her learners and promoted an ethos of sharing among them. She encouraged sharing of items in a good way without making any of her learners feel uncomfortable. Some groups had less variety in terms of the fruit that each learner within the group had brought to class. She suggested that groups swop fruit to ensure that they had more 
variety in making the fruit salad. In so doing she attempted to foster a culture of sharing and cooperation among her learners.

She was alert to race issues as well. A white boy seized an opportunity to move away from a black learner by going to another group and sitting next to another white boy. Mrs Coetzee in a very professional manner and without much fuss made it clear that learner shifts were unacceptable and calmly requested that the learner "swop back please", to which the learner quietly acceded.

\section{Vignette 2}

This was a Life Orientation lesson based on emotions and love. The lesson commenced with Mrs Coetzee congratulating three learners who had celebrated their birthdays during the week. She took time to make them feel special and reminded them to collect a KFC voucher from her at the end of the lesson (a sponsorship initiative undertaken by Mrs Coetzee).

The lesson was introduced with an activity that required learners to color in a worksheet that had faces drawn on it. Mrs Coetzee instructed learners to "color in one of the faces that you think represents you today." This was a way for her to be in touch with learners' emotions and to link this real-life experience to new knowledge. An attempt was then made by Mrs Coetzee to link the new learning to the relevant previous knowledge of learners by referring to a past assembly talk. The assembly talk used the analogy of a suitcase for trying to carry someone's burden. The question was posed to learners: What do you think carries us through hard times? Learners responded "Madam you love us all." "Love is what carries us through." Mrs Coetzee then shared some snippets of her life with learners and concluded this section with the statement "We are all angels with one wing and need each other to fly."

Learners were then requested to take out the "Valued Citizenship book" and complete the relevant activities on the topic "Emotions and Love" in groups of five. Each group was assigned a hypothetical case study based on the topic. Energetic, enthusiastic and stimulating group discussions ensued. Each group was required to provide feedback. Groups offered different reasons and different solutions. For example,

Mrs Coetzee: Okay class, lets see what you have discovered from your story. I am going to ask the group leader of each group to provide feedback.

Ayesha (group 1): Mam, we think it is about accepting others.

Mrs Coetzee: Can you tell me why your group thinks this?

Ayesha: Because if we don't accept each other then we cannot love each other.

Tim (group 2): We thought it is about the love and tolerance.

Mrs Coetzee: Why do you say this? 
Tim: Because mam, we must learn to live together then there will be no hatred.

Lindiwe (group 3): Our group thinks it's all about misunderstandings. We need to learn to accept people who are different from us.

Mrs Coetzee: How will this help us?

Lindiwe: We will then stop fighting and will all be happy.

Positive feedback was provided to learners all the time. Mrs Coetzee constantly motivated learners and encouraged learner participation in the form of critical inquiry and reflective engagement. Many "why" questions were posed. Given the nature of the topic Mrs Coetzee reacted to the collective feedback in the following manner: "To be different is not wrong, you are entitled to your opinion." She continuously reminded learners whose answers she had not written on the chalkboard that it was not because their answers were wrong or unimportant; it was only because they overlapped with what had already been mentioned by others. This could be analyzed as a way of making all learners feel that they have a contribution to make and that their opinions are valued. Learners were thus encouraged to put their views forward as a result of this reassurance. The lesson was consolidated with discussions about love, misunderstanding, acceptance, tolerance, negotiation and communication.

So class what did we learn about emotions and love today? We learnt that we need to accept and tolerate each other, no matter how different we are. We also learnt that if we do not communicate with each other there will be misunderstandings. We also learnt that we need to negotiate with each other by talking to each other. If we can do all this then there will be love and happiness (Mrs Coetzee).

Mrs Coetzee aptly related the outcomes of the lesson to the real-life experiences of learners and to the social context. She shared snippets of her own experiences and allowed learners to see that she too had human flaws. In encouraging critical inquiry she referred to an occurrence that many learners were exposed to on a daily basis, to stress the importance of learning: "Don't end up like the beggars holding placards at the robots, take charge of your life by learning."

\section{Analysis and Discussion of Findings}

"Conversion" or "Gestalt shift:" Professed beliefs cohered with practices. According to Sheehy (1981) the embrace of change only happens with an inner change in people's beliefs. A shift in Mrs Coetzee's (a white Afrikaans-speaking teacher who taught in a former white school, exclusively to white students) beliefs and practices were evident in the above findings. While it is thought that beliefs are resistant to change (Schraw \& Olafson, 2002), shifts can occur by means of a "conversion or gestalt shift" (Nespor, 1987). These shifts can be immediate and decisive. It appears that Mrs Coetzee's belief about viewing diversity as an asset rather than as a deficit was pivotal in this conversion. 
They fill me with a most beautiful variety of multicultural love, humor, religions and they make me the richest person in the world.

Rather than nostalgically holding on to the past as did so many of her counterparts, Mrs. Coetzee was prepared to make a paradigm shift. She proactively set out to make a difference by positively internalizing and embracing educational change. As Goodson (2001) claims, effective educational change requires personal and internal commitment or ownership. She believed that change began with her. She needed to change so as to embrace external change. Several argumentations from previous studies also found that educational change is most successful when conducted by teachers as part of their personal and professional projects and where teachers take ownership of the reform (Goodson \& Hargreaves, 1996; McClaughlin \& Yee, 1988; Sheehy, 1981). The change began with a transformation of her perceptions and projected outwards into the social and institutional domain. She saw the beauty and wealth of affirming diversity and felt personally enriched by adopting an inclusive and asset-based approach in her teaching. Her professed beliefs cohered well with her practices (Mitchell \& Koedinger, 2000). Diversity was affirmed in this classroom not only in terms of first order changes i.e. changes in learner population; the celebratory approach to diversity, posters on classroom walls, etc. but also in terms of second order changes i.e. changes in curriculum and changes in the visible symbols associated with the dominant racial culture and history of school.

We take turns to greet each other at least once every two weeks in somebody's mother tongue. We share funny cultural stories. We share what good manners in one culture could be seen as bad manners in another. We share cultural songs and dances. My children teach me and the rest of the class three words of a different language every day.

She not only examined her beliefs about teaching a class of diverse learners but she also explored the effectiveness of her practices in accommodating the various cultures, lifestyles, and learning styles of her students (Cabello \& Burstein, 1995; Ladson-Billings, 1995; Reinke \& Moseley, 2002). Mrs Coetzee was willing to cross cultural borders which required a renegotiation of her beliefs and ideas in an attempt to understand and assimilate the values and beliefs of her diverse learners. She demonstrated the ability to understand her own belief system as well as the value system of her learners and in this way was successful not only in responding to the diversity in her classroom, but in creating a space where all could feel a sense of belonging and feeling at home. She believed "we are all angels with one wing and need each other to fly."

The personal beliefs and missions that she brought to the change process, was given importance and thus the lens shifted to focus on how she changed internally and then how this personal change then influenced institutional change and more broadly, societal change (Goodson, 2001; Sheehy, 1981). 


\section{What should Change and how to Go about it}

In the South African context there is much literature on what should change, but there is very little on what strategies can be implemented to effect change in teachers' beliefs about diversity. Educational change involves what changes to implement and how to implement them. These aspects interact and shape each other (Fullan, 2001). This section attempts to outline some of the strategies utilized by Mrs Coetzee to embrace meaningful educational change in a diverse classroom namely, classroom climate and atmosphere, authority and discipline, teacher preparedness, teaching strategies, communication, in touch with personal lives of learners, inculcating an inquiring mind, ethos of sharing, pastoral role of the teacher and dispelling stereotypes.

In attempting to create a classroom climate and atmosphere that was conducive to creating educational opportunities for all learners, Mrs Coetzee transformed an otherwise rather old classroom with outdated furniture into an inviting, colorful, bright and stimulating educative environment. Furthermore, she endorsed an inclusive approach and ensured that all cultures were represented in her classroom in terms of first order changes and in so doing set the tone and created an atmosphere where all could feel a sense of belonging.

We share food and make a fuss about cultural or religious occasions. They may bring cultural dishes to school for us to taste, especially on cultural and religious holidays. I display a variety of cultural objects and artifacts in my classroom. Several argumentations from previous studies (Ball \& Cohen, 1999; Fullan, 2001; National Research Council, 1999; McLaughlin \& Mitra, 2000; Sheehy, 1981; Stigler \& Hiebert, 1999) claim that changes in belief and understanding are the foundation of achieving lasting reform because they are based on fundamental changes in conception, which, in turn, relate to skills and materials.

Mrs Coetzee had excellent rapport with her learners, which in turn fostered good discipline in the class. Learning was infused with a sense of humor and fun. She tried to "edutain" her learners,

I really become a child when I am teaching. I get excited about things that excites my children for example, I watch movies with my own daughter and use this information when I do my lessons i.e. social science lesson about "human rights" by making use of the video "Balto" - the children relate to this and learning takes place easily.

Furthermore, she displayed empathy and was an attentive listener. She respected every learner in her class and enacted her philosophy of building the positive selfesteem of every individual in her class. "So what if your shoes are broken? Your spirit is intact! YOU ARE SPECIAL. I want to save each and every child from having a low self-esteem." 
Despite the fact that there were forty learners in her class, Mrs Coetzee had taken the time to get to know and understand each individual in her class. She was in touch with the personal lives of learners, "Daddy called you all the way from England." She tried to get in touch with the emotions of her learners, "Color in the face that you think represents you today." "Come give me a hug."

I consider my children's feelings - when they know that you respect how they feel, they react a lot more positively towards learning.

In all her lessons Mrs Coetzee tried to inculcate critical thinking and to foster an inquiring mind. For example, in the first lesson she asked: Why do you think we made a fruit salad today? Her second lesson was also infused with many why questions? She constantly probed her learners and pushed them to think and reflect on what they were learning. There was no evidence of rote learning, neither was there place in her class for monosyllabic responses. Learners could not just simply answer with a "yes" or "no" response. They had to provide justification for their responses. Coupled to this, responses were linked to examples of real-life situations within the social context of South Africa.

Aside from infusing every lesson with sound moral values, Mrs Coetzee promoted an ethos of sharing and cooperation among learners. For example, some groups had fewer variety in terms of the fruit that each learner within the group had brought to class. She suggested that groups swop fruit to ensure that they had more variety in making the fruit salad. Mrs Coetzee had a very caring disposition towards her learners. She made learners feel safe, secure and welcomed in learning spaces.

She tried to address stereotyping and in so doing empowered her learners about issues of race and identities. "We make fun of things in our cultures; clean nice fun. For example, are all blondes stupid? She encouraged learners to discuss such issues and they then began to empathize with the situation by putting themselves in the shoes of another. She tried to dispel stereotypes that were created in society by getting her learners to think critically and begin to challenge these stereotypes in society. In so doing she promoted an "epistemology and a pedagogy of compassion."

In implementing educational change Mrs Coetzee clearly "changed her practice" along all three dimensions identified by Fullan (2001, p. 38) namely, (1) the possible use of new or revised material, including instructional resources such as curriculum materials or technologies; (2) the possible use of new teaching approaches; and (3) the possible alteration of beliefs such as the pedagogical assumptions and theories underlying new policies or programmes, for it to have a lasting outcome. 


\section{The Personal Domain of the Teacher in Sustaining Educational Change}

It was evident that change began with the personal change of the teacher. Goodson's (2001) underscores the centrality of the personal domain of the teacher in sustaining educational change. Mrs Coetzee like all teachers across South Africa was exposed to a constant barrage of top-down education policies. In an environment where change seemed to be unfolding as political symbolism, that lacked personal or internal commitment and ownership, she stood out as a shining beacon of hope. She became a champion of change and wanted to make a difference in the lives of her learners. She embraced differences and adopted and inclusive approach that was imbued with human compassion and empathy and emphatically demonstrated a balance between the internal, the external and the personal perspectives of change (Goodson, 2001; Sheehy, 1981).

\section{The Fluidity and Susceptibility of Identity to Change}

At a time when most institutions were grappling with issues of power and using the history and hegemonic culture of the school to preserve their identities and enforce assimilatory practices, Mrs Coetzee chose to go against the grain. Her conduct revealed that although identity is created from the ingredients of a personal past it is always in a process of transformation (Hall, 1996a, 1996b) focused on becoming rather than being (Gilroy, 2001) formed in accordance with how she was positioned by and positioned herself with respect to the past (Hall, 1996c) and was susceptible to change (Goodson, 2001). The dynamics within her classroom were illustrative of the fact that different cultures interact in a third space (Bhabha, 1994) in which boundaries and borders become porous. In this blurring of cultural and economic borders, identity is constantly being reinvented and renegotiated (Barker, Hulme, \& Iversen, 1994; Gandhi, 1998; Hall, 1996c).

\section{Conclusion}

It is evident that the beliefs Mrs Coetzee held influenced her perceptions and the way she taught. Her professed beliefs cohered well with her practices and played a significant role in how she responded to diversity in her classroom. For Mrs Coetzee, teaching is much more than being sensitive and sensitized to diverse cultural backgrounds of students. It is about moving teaching and learning away from the deficit approach or a "culture of poverty" to embracing an asset-based approach and "funds of knowledge." It is about recognizing how cultures are contextually based and necessitates that teachers become culturally competent in order to meaningfully and appropriately incorporate students cultural and linguistic backgrounds into their teaching. Mrs Coetzee's pedagogy supported students by sustaining the cultural and

4 Culture of poverty: where the home cultures and communities of marginalised students were bankrupt of any languages or cultural practices of value in schools and society. 
linguistic competence of their communities, while at the same time offering access to dominant cultural competence. In this way she was an active proponent of "culturally sustaining pedagogy." Such incorporation not only validates students' identities, but also validates their home-based knowledge and experiences and allows them to participate in constructing what counts as knowledge in their classrooms and schools (Castagno \& Brayboy, 2008).

Mrs Coetzee was extremely passionate about her calling as a teacher. Her spirit and her love for teaching were not dampened by the social context within which she found herself. If anything, it seemed to fuel her passion for teaching. This passion combined with critical thinking, self-reflective skills and socio-cultural justice education served to foster culturally sustaining pedagogy and socio-cultural responsive teaching in her classrooms. In so doing, teaching became a class act of human compassion. Her beliefs translated into practice and served to reinstate the balance between the internal, the external and the personal perspectives of change. She firmly believed in the saying "Be the change you wish to see in the world" (Mahatma Gandhi) and became an active agent of meaningful educational change. Instead of spending exorbitant sums of money on ever-changing curricula reforms and teacher appraisal systems, in the fervent hope that it would be appropriated by teachers, perhaps it is time that the National Department of Education, curriculum designers, policy-makers, provincial and district officials pay increasing attention to the personal missions and purposes that underpin teachers' commitment to education change processes. In addition, teacher training programmes should incorporate culturally sustaining pedagogy and socio-cultural responsive teaching to effectively prepare teachers for practice in a class of diverse learners.

\section{References}

Aikenhead, G. S. (1996). Science Education: Border Crossings into the Subculture of Science. Studies in Science Education, 27, 1-52.

Ambrose, R., Clement, L., Phillip, R., \& Chavot, J. (2004). Assessing prospective elementary school teacher's beliefs about mathematics and mathematics learning: Rationale and development of a constructed-response format belief survey. Social Science and Mathematics, 104(2), 56-69.

Angrosino, M. V. (2005). Recontextualizing observation: Ethnography, pedagogy, and the prospects for a progressive political agenda. In N. K. Denzin \& Y. S. Lincoln. (Eds.), The sage handbook of qualitative research (3rd ed., pp. 729-745). Thousand Oaks, CA: Sage.

Baca, L., \& Cervantes, H. T. (1989). The bilingual special education interface. Columbus, OH: Merrill.

Ball, D., \& Cohen, D. (1999). Developing practice, developing practitioners: Towards a practicebased theory of professional education. In L. Darling-Hammond \& G. Sykes (Eds.), Teaching as the learning profession (pp. 3-32). San Francisco, CA: Jossey-Bass.

Baltar, F., \& Brunet, I. (2012). Social research 2.0: Virtual snowball sampling method using Facebook. Internet Research, 22(1), 57-74. 
Bandura, A. (1986). Social foundations of thought and action: A social cognitive theory. Englewood Cliffs, NJ: Prentice Hall.

Banks, J. A., \& Banks, C. A. M. (Eds.). (2001). Multicultural education: Issues \& perspectives (4th ed.). New York, NY: Wiley.

Barker, F., Hulme, P., \& Iversen, M. (1994). Introduction. In F. Barker, P. Hulme, \& M. Iversen (Eds.), Colonial discourse/postcolonial theory (pp. 1-23). Manchester, UK: Manchester University Press.

Bhabha, H. K. (1994). The location of culture. London, UK: Routledge.

Butler-Kisber, L. (2010). Qualitative Inquiry. Thematic, narrative and arts-informed perspectives. London, UK: Sage.

Cabello, B., \& Burstein, N. D. (1995). Examining teachers' beliefs about teaching in culturally diverse classrooms. Journal of Teacher Education, 46(4), 285-294.

Castagno, A. E., \& Brayboy, B. M. J. (2008). Culturally responsive schooling for indigenous youth: A review of the literature. Review of Educational Research, 78, 941-993.

Charmaz, K. (2005). Grounded theory in the 21st century: Applications for advancing social justice studies. In N. K. Denzin \& Y. S. Lincoln (Eds.), The Sage handbook of qualitative research (3rd ed., pp. 507-535). Thousand Oaks, CA: Sage.

Corbett, D., \& Wilson, B. (2002). What urban students say about good teaching. Educational Leadership, 60(1), 18-22.

Department of Education. (1997). The South African Schools'Act. Act no.37 of 1997.

Dewey, J. (1933). How we think: A restatement of the relation of reflective thinking to the educative process. Boston, MA: D. C. Heath \& Co.

Fiske, E. B., \& Ladd, H. F. (2004). Elusive equity: Education reform in post-apartheid South Africa. Washington, DC: Brookings Institute.

Fullan, M. G. (1991). The new meaning of educational reform (2nd ed.). New York, NY: Teachers College Press.

Fullan, M. G. (1998). The meaning of educational change. In A. Hargreaves, A. Lieberman, M. Fullan, \& D. Hopkins (Eds.), International handbook of educational change (pp. 544-557). Dortrecht: Kluwer Academic Publishers.

Fullan, M. G. (2000). The return of large-scale reform. The Journal of Educational Change, 1(1), 5-28.

Fullan, M. G. (2001). The new meaning of educational change (3rd ed.). New York, NY: Teachers College Press.

Fullan, M. G. (2003). Leading in a culture of change. San Francisco, CA: Jossey-Bass.

Gandhi, L. (1998). Postcolonial theory: A critical introduction. New York. NY: Columbia.

Garibaldi, A. (1992). Preparing teachers for culturally diverse classrooms. In M. E. Dilworth (Ed.), Diversity in teacher education: New expectations (pp. 23-39). San Francisco, CA: Jossey Bass.

Gilroy, P. (2004). After empire Melancholia or convivial culture? London, UK: Routledge.

Goodman, J. (1988). Constructing a practical philosophy of teaching: A study of pre-service teachers' professional perspectives. Teaching and Teacher Education, 4, 121-137.

Goodson, I. F. (2001). Social histories of educational change. Journal of Educational Change, 2, 45-63.

Goodson, I. F., \& Hargreaves, A. (1996). Teachers' professional lives. London and Philadelphia: Falmer Press. 
Goodwin, A. L. (1997). Multicultural stories: Pre-service teachers' conceptions of and responses to issues of diversity. Urban Education, 32(1), 117-145.

Hall, S. (1996a). New ethnicities. In D. Morley \& C. Kuan-Hsing (Eds.), Stuart Hall: Critical dialogues in cultural studies (pp. 252-260). London, UK: Routledge.

Hall, S. (1996b). What is 'black' in black popular culture? In D. Morley \& C. Kuan-Hsing (Eds.), Stuart Hall: Critical dialogues in cultural studies (pp. 21-37). London, UK: Routledge.

Hall, S. (1996c). Cultural identity and diaspora. In P. Mongia (Ed.), Contemporary postcolonial theory: A reader (pp. 110-121). London, UK: Arnold.

Hargreaves, A. (2000). Representing educational change. Journal of Educational Change, 1(1), 1-3.

Harley, K., \& Wedekind, V. (2004). Political change. Curriculum change and social formation, 1990-2002. In L. Chisholm (Ed.), Changing class, education and social change in postapartheid South Africa (pp. 195-220). Cape Town, South Africa: Human Sciences Research Council Press.

Hopkins, D. (2000). Tensions in and prospects for school improvement. In A. Hargreaves, A. Lieberman, M. Fullan, \& D. Hopkins (Eds.), International handbook of educational change (pp. 1035-1059). Dortrecht, The Netherlands: Kluwer Academic Publishers.

Jansen, J. D. (2001). Image-ing teachers: Policy images and teacher identity in South African classrooms. South African Journal of Education, 21(4), 242-246.

Jansen, J., \& Christie, P. (Eds.). (1999). Changing curriculum: Studies on outcomes-based education in South Africa. Cape Town, South Africa: Juta and Co Ltd.

Jansen, J., \& Taylor, N. (2003). Educational change in South Africa 1994-2003: Case studies in large scale education reform. Washington, DC: World Bank.

Jita, L. (2002, March). Teacher's identities and science teaching: A South African case study. Paper presented at the Comparative International Education Society Conference in Florida.

Kagan, D. M. (1992). Professional growth among pre-service and beginning teachers. Review of Educational Research, 62(2), 129-169.

Kauchak, D., \& Burbank, M. D. (2003). Voices in the classroom: Case studies of minority teacher candidates. Action in Teacher Education, 25(1), 63-75.

Ladson- Billings, G. (1995). Toward a theory of culturally relevant pedagogy. American Educational Research Journal, 32(3), 465-491.

Leder, G. C., Pehkonen, E., \& Törner, G. (2002). Beliefs: A hidden variable in mathematics education? Boston, MA: Kluwer Academic Publishers.

Lloyd, G. (2003). Mathematics teachers' beliefs and experiences with innovative curriculum materials: The role of curriculum in teacher development. In G. Leder, E. Pehkonen, \& G. Toemer (Eds.), Beliefs: A hidden variable in mathematics education? (pp. 149-159). Dordrecht, The Netherlands: Kluwer.

Mayring, P. (2000). Qualitative content analysis. Forum for qualitative research: Qualitative Social Research. On-line Journal, 1(2). Retrieved March 26, 2010 from http:/qualitativeresearch.net/ fqs/fqs-e/2-00inhalt-e.htm

McClaughlin, M. W., \& Yee, S. M. (1988). School as a place to have a career. In A. Lieberman (Ed.), Building a professional culture in school (pp. 23-44). New York, NY: Teachers College Press.

McLaughlin, M., \& Mitra, D. (2000). Theory-based change and change-based theory: Going deeper, going broader. Unpublished paper, Stanford University, Stanford, CA. 
McMillan, J., \& Schumacher, S. (2001). Research in education: A conceptual introduction. New York, NY: Longman.

Mitchell, N., \& Koedinger, K. R. (2000). An investigation of teachers' beliefs of students' algebra development. Cognition and Instruction, 18(2), 46-70.

Mueller, D. (1986). Measuring social attitudes: A handbook for researchers and practitioners. New York, NY: Teachers College Press.

National Research Council. (1999). Improving student learning. Washington, DC: National Academy Press.

Nespor, J. (1987). The role of beliefs in the practice of teaching. Journal of Curriculum Studies, 19(4), 317-28.

Nkomo, M., \& Vandeyar, S. (2008). In search of best practice in South African desegregated schools. Cape Town: Human Sciences Research Council.

Pohan, C. A. (1996). Pre-service teachers' beliefs about diversity: Uncovering factors leading to multicultural responsiveness. Equity and Excellence in Education, 29(3), 62-69.

Reinke, K., Moseley, C. (2002). The effects of teacher education on elementary and secondary preservice teachers' beliefs about integration. A longitudinal study. Action in Teacher Education, 24, 31-39.

Roediger, D. (2003). Colored white: Transcending the racial past. Journal of Sociology and Social Welfare, 30(3), 23-38.

Ross, R. (1994). The ladder of inference. The Fifth Discipline Fieldbook, (pp. 242-243). New York, NY: Doubleday.

Rubin, A., \& Babbie, E. R. (1993). Research methods for social work (2nd ed.). Pacific Grove, CA: Sage.

Sandelowski, M. (2000). Focus on research methods. Whatever happened to qualitative description? Research in Nursing and Health, 23, 334-340.

Sarason, S. (1996). Barometers of change: Individual, institutional, social transformation. San Francisco, CA: Jossey-Bass.

Sayed, Y. (2001). Post-apartheid educational transformation: Policy concerns and approaches. In Y. Sayed \& J. Jansen (Eds.), Implementing education policies. The South African experience (pp. 3-22). Cape Town, South Africa: UCT Press.

Schraw, G., \& Olafson, L. (2002). Teachers' epistemological worldviews and educational practices. Issues in Education, 8(2). Retrieved from http://web7.epnet.com/citation.asp?

Seale, C. F. (2002). Quality issues in qualitative inquiry. Qualitative Social Work, 1(1), 97-110.

Sheehy, G. (1981). Path finders: How to achieve happiness by conquering life's crisis. London, UK: Sidgwick \& Jackson.

Sieborger, R., \& Nakabugo, M. (2001). Curriculum reform and teaching in South Africa: Making a "paradigm shift?." International Journal of Education Development, 21, 53-60.

Silverman, D. (2006). Doing qualitative research (2nd ed.). London, UK: Sage.

Sleeter, C. E. (1992). Multicultural education: Five years. The Education Digest, 57(7), 53-57.

Spradley, J., \& McCurdy, D. (1987). Culture and the contemporary world. In J. Spradley \& M. McCurdy (Eds.), Conformity and conflict: Readings in cultural anthropology (6th ed., pp. 1-10). Boston, MA: Little, Brown, and Company. 
Stigler, J., \& Hiebert, J. (1999). The teaching gap. New York, NY: The Free Press.

Taylor, N., \& Vinjevold, P. (1999). Getting learning right: Report to the president's education initiative research project. Johannesburg: Joint Education Trust.

Thompson, A. G. (1992). Teachers' beliefs and conceptions: A synthesis of the research. In D. Grouws (Ed.), Handbook of research on Mathematics teaching and learning (pp. 127-146). New York, NY: Macmillan.

Vandeyar, S. (2006). Teacher-Student interactions in desegregated classrooms in South Africa. International Journal of Educational Development, 26(4), 362-393.

Vandeyar, S. (2010). Responses of South African teachers to the challenge of school integration. South African Journal of Education, 30, 343-359.

Vandeyar, S. (2013). Teaching a class act of human compassion. Mediterranean Journal of Social Science, 5(8), 57-61.

Vandeyar, S., \& Jansen, J. (2008). Diversity high: Colour, character and culture in a South African high school. USA: University Press of America.

Vandeyar, S., \& Killen, R. (2003). Has curriculum reform in South Africa really changed assessment practices, and what promise does the revised National Curriculum Statement hold? Perspectives in Education, 2(11), 119-134.

Walsh, J. P., \& Charalambides, L.C. (1990). Individual and social origins of belief structure change. Journal of Social Psychology, 130(4), 517-532.

Wilson, M. R., \& Cooney, T. (2003). Mathematics teacher change and development: The role of beliefs. In G. Leder, E. Pehkonen, \& G. Toemer (Eds.), Beliefs: A hidden variable in mathematics education? (pp. 127-147). Dordrecht, The Netherlands: Kluwer. 
